\title{
EUROPEAN JOURNAL FOR PHILOSOPHY OF RELIGION
}

\section{A Perpetual Present: Henri Bergson and Atemporal Duration}

Author: Matyáš MORAVEC (https://orcid.org/0000-0001-8477-6065)

Affiliation: University of Cambridge

E-Mail Contact: mm2153@cam.ac.uk

Keywords: Henri Bergson, atemporal duration, Stump and Kretzmann, la durée, eternity

\section{Abstract}

The aim of this paper is to demonstrate that adjusting Stump and Kretzmann's "atemporal duration" with la durée, a key concept in the philosophy of Henri Bergson (1859-1941), can respond to the most significant objections aimed at Stump and Kretzmann's reinterpretation of Boethian eternity. This paper deals with three of these objections: the incoherence of the notion of "atemporal duration," the impossibility of this duration being time-like and the problems involved in conceiving it as being related to temporal duration by a relation of analogy. I conclude that "atemporal duration" (which has unfortunately come to be regarded with suspicion by most analytic philosophers of religion) - when combined with Bergson's durée to become an "atemporal durée" - is a coherent understanding of divine eternity.

\section{Introduction}

The aim of this paper is to demonstrate that adjusting Stump and Kretzmann's "atemporal duration" ${ }^{1}$ with la durée, a key concept in the philosophy of Henri Bergson (1859-1941), can

\footnotetext{
${ }^{1}$ See Eleonore Stump and Norman Kretzmann, "Eternity", The Journal of Philosophy 78, no. 8 (1981).
} 
respond to the most significant objections aimed at their re-interpretation of Boethian eternity. ${ }^{2}$

Despite the fact that a significant part of the debate triggered by Stump and Kretzmann's "Eternity" (1981) took place over twenty years ago, it remains a locus classicus for treatments of the relation between God and time in analytic philosophy of religion. ${ }^{3}$ This paper positions itself in line with constructive developments of the notion of eternity as "atemporal duration" proposed by Stump and Kretzmann, which has now been predominantly abandoned by the majority of analytic philosophers. Responding to the objections by strengthening their intuitions about divine timelessness with Bergson's philosophy could reintroduce "atemporal duration" as a legitimate option when considering the nature of eternity.

Recent years have seen a resurgence of interest in Bergson's philosophy of time outside the continental tradition to which he is most usually consigned. ${ }^{4}$ Bergson's thought seems worth investigating within the context of analytic philosophy of religion, not only because of Bergson's connection with Boethius through his interest in Neoplatonism, ${ }^{5}$ but also because Bergson and analytic philosophy of religion share an extensive list of common questions (e.g., the problem of free will, ${ }^{6}$ the disanalogies between space and time, or the nature of possibility and necessity). This paper will show that a Bergsonian understanding of divine time can neutralise the apparent antinomic trichotomy between the following:

\footnotetext{
2 Boethius, The Consolation of Philosophy (Harvard University Press, 1973), 423.

${ }^{3}$ See for example J. Diekemper, "Eternity, Knowledge and Freedom", Religious Studies 49, no. 1 (2013); Ryan T. Mullins, "Simply Impossible: A Case Against Divine Simplicity", Journal of Reformed Theology 7, no. 2 (2013); C. De Florio and A. Frigerio, "In Defense of the Timeless Solution to the Problem of Human Free Will and Divine Foreknowledge", International Journal for Philosophy of Religion 78, no. 1 (2015); Paul Helm, "Eternity and Vision in Boethius", European Journal for Philosophy of Religion 1, no. 1 (2009).

${ }^{4}$ See for example A. Mutch, "The Limits of Process: On (Re)Reading Henri Bergson", Organization 23, no. 6 (2016); Stephen E. Robbins, "On Time, Memory and Dynamic Form”, Consciousness and Cognition 13 (2004), 762-88; Clifford Williams, "A Bergsonian Approach to A- and B-Time”, Philosophy 73, no. 285 (1998); Sonja Deppe, "The Mind-Dependence of the Relational Structure of Time (or: What Henri Bergson Would Say to BTheorists)", Kriterion - Journal of Philosophy 30, no. 2 (2016); Sebastian Olma, "Physical Bergsonism and the Worldliness of Time", Theory, Culture \& Society 24, no. 6 (2007), 123-37; Adam Riggio, "Lessons for the Relationship of Philosophy and Science From the Legacy of Henri Bergson", Social Epistemology 30, no. 2 (2016).

${ }^{5}$ See W. J. Hankey, One Hundred Years of Neoplatonism in France: A Brief Philosophical History (Peters, 2006), 106-19; Rose-Marie Mossé-Bastide, Bergson et Plotin (Presses Universitaires de France, 1959); Henri Bergson, Histoire de l'idée de temps. Cours au Collège de France 1902-1903 (Presses Universitaires de France, 2016).

6 See for example Michael Rota, "The Eternity Solution to the Problem of Human Freedom and Divine Foreknowledge", European Journal for Philosophy of Religion 2, no. 1 (2010); Christoph Jäger, "Molinism and Theological Compatibilism", European Journal for Philosophy of Religion 5, no. 1 (2013).
} 
(i) regarding God's time as a static, frozen, lifeless instant, ${ }^{7}$ (ii) claiming that God's life is not such an instant, that it has extended duration, although this duration cannot be divided into subphases (Stump and Kretzmann), (iii) regarding "atemporal duration" as not consisting of discrete subphases and yet as having ordered relations between its points (Brian Leftow's quasi-temporal eternity ${ }^{8}$ ). Such a project requires some crucial qualifications:

First, I will not engage with the debate about A- and B- series. This is because unless indicated otherwise - the considerations of God's relation to time which I will be discussing below apply to A- and B-theories of time equally. Perhaps more importantly, despite my partial reservations about his interpretation of Bergson, I side with the conclusion of C. Williams' argument which attempts to show that Bergson's critique applies to both sides of the A-B distinction. ${ }^{9}$ It might be still be said, however, as R. T. Mullins does, ${ }^{10}$ that although the A- and B-series may not be crucial to debates about God and Time, there still remains a fundamental ontological difference between presentism, eternalism and the growing-block theory. This is a general problem for any conception of the God-time relation that insists on omniscience. I will briefly discuss this problem in section 5 .

Second, it is important to note that there is a threefold movement in the trajectory of the Bergsonian corpus. In his earliest works, la durée is used primarily as an epistemological category pertaining to the phenomenology of time in consciousness. ${ }^{11}$ Later, it "moves outwards" and is attributed to the external world, ${ }^{12}$ concluding with the claim about a hierarchy of durations, creating a "super-science"13 of durées in Creative

\footnotetext{
${ }^{7}$ For a critique of the "lifelessness" of the eternal instant, see William Kneale, "Time and Eternity in Theology", Proceedings of The Aristotelian Society 61 (1985); Richard Swinburne, The Coherence of Theism (Oxford University Press, 2016), chapter 12; Robert C. Coburn, "Professor Malcolm on God", Australasian Journal of Philosophy 41, no. 2 (1963), 155-56; William Hasker, God, Time and Knowledge (Cornell University Press, 1989), 151; Richard Swinburne, "God and Time", in Reasoned Faith: Essays in Honor of Norman Kretzmann, ed. Eleonore Stump (Cornell University Press, 1993), 216; Paul Helm, Eternal God. A Study of God without Time (Oxford University Press, 2010).

${ }^{8}$ See Brian Leftow, "Boethius on Eternity", History of Philosophy Quarterly 7, no. 2 (1990).

${ }^{9}$ See Williams, "A Bergsonian Approach to A- and B-Time"; Clifford Williams, "The Metaphysics of A- and BTime", The Philosophical Quarterly 46, no. 194 (1996).

${ }^{10}$ See Ryan T. Mullins, The End of the Timeless God (Oxford University Press, 2016), 22-30.

${ }^{11}$ See Henri Bergson, Essai sur les données immédiates de la conscience (Presses Universitaires de France, 2013).

${ }^{12}$ See Henri Bergson, Matière et mémoire. Essai sur la relation du corps à l'esprit (Presses Universitaires de France, 2012).

${ }^{13}$ Jean Milet, Bergson et le calcul infinitésimal ou La raison et le temps (Presses Universitaires de France, 1974), 100.
} 
Evolution. ${ }^{14}$ The question about where it is legitimate to stop this move from an ontological perspective is rather complicated. ${ }^{15}$ For the purposes of this paper, where I will be talking about divine duration as a mode of God's being, it suffices to limit Bergson's views to the first stage. That is, I identify durée with the time of consciousness immediately accessible by introspection.

Third, I will not be engaging with the problems of ET-simultaneity: my aim is solely to investigate "atemporal duration" which I take to be separate and separable from it. ${ }^{16}$

In what follows, I will first provide a short account of the relevant features of Bergson's philosophy of time. Second, I will outline key aspects of Stump and Kretzmann's "atemporal duration" and objections against it. In the third part, I will stipulate that the "duration" in "atemporal duration" be taken as equivalent to Bergson's la durée and demonstrate how such a stipulation responds to these objections.

\section{Bergson on Time}

The main emphasis of Bergson's thought is on the radical difference between time and space:

All through the history of philosophy time and space have been placed on the same level and treated as things of a kind; the procedure has been to study space, to determine its nature and function, and then to apply to time the conclusions thus reached.... To pass from one to the other one had only to change a single word: 'juxtaposition' was replaced by 'succession.' ${ }^{17}$

Bergson thinks that this confusion is most pertinent in the way philosophy since Kant has understood the time of consciousness. Symptomatic of this confusion, Bergson says, is the frequent appeal to the analogy of a line as a helpful tool to schematise the progression of mental states in our mind: 18

\footnotetext{
${ }^{14}$ See Henri Bergson, L'Évolution créatrice (Presses Universitaires de France, 2007).

${ }^{15}$ See Frédéric Worms, "Les trois dimensions de la question de l'espace dans l'œuvre de Bergson", Épokhè 94, no. 4 (1994), especially 101-109.

${ }^{16}$ For a survey of objections against ET-simultaneity, see Delmas Lewis, "Eternity Again: A Reply to Stump and Kretzmann", International Journal for Philosophy of Religion 15, no. 1/2 (1984); Helm, Eternal God. A Study of God without Time. I fully endorse Helm's claim that 'ET-simultaneity has no independent merit or use, nothing is illuminated or explained by it. Its sole purpose is to avoid the alleged reductio [by Kenny and Swinburne], which it does' (idem, 33) and that 'while [it] is formally consistent it does not actually advance understanding.' (idem, 97)

${ }^{17}$ Henri Bergson, Creative Mind (Dover Publications, 2007), 4.

${ }^{18}$ See for example Immanuel Kant, Critique of Pure Reason (Cambridge University Press, 1998), A33/B50.
} 
we set [our states of consciousness] side by side in such a way as to perceive them simultaneously, ... alongside one another; in a word, we project time into space, we express duration [la durée] in terms of extensity, and succession thus takes the form of a continuous line or a chain, the parts of which touch without penetrating one another. ${ }^{19}$

Specifically, the moment we start to think about mental states given to our consciousness as forming a succession, we presume that some of them come "before" or "after" others. However, Bergson argues that for two of our mental states to be related by a "before and after" relation, they both have to be accessible to consciousness at once, i.e., at the same time, similarly to the way that objects in space coexist. ${ }^{20}$ The "time" that we normally appeal to when considering the temporal development of our consciousness is a primary example of what Bergson calls "spatialized time" (le temps spatialisé). ${ }^{21}$ Understanding our consciousness as line-like (analogous to and representable by a line progressing in space) and potentially homogeneous (i.e., divisible into intervals equal in length) is primarily driven by practical utility. One need only to realise how useful it is to conceive time in this way: our calendars are based on the possibility of representing past, present and future appointments "coexisting together" on a single page of our journal, laid out simultaneously in two-dimensional space.

Bergson argues that the notion of homogeneity is simply a reaction against the heterogeneity that lies at the bottom of our conscious experience. ${ }^{22}$ This heterogeneity consists of Bergson's key concept of la durée. La durée is a concept notoriously difficult succinctly to describe, not least due to its opposition to ordinary conceptual ways of thinking implicated by language - it is precisely its resistance to a simple description by language, similarly to the difficulty in describing the content of qualia, for example, that has contributed to its neglect in early analytic philosophy. ${ }^{23}$ Nevertheless, similarly to qualia, it

\footnotetext{
${ }^{19}$ Henri Bergson, Time and Free Will. An Essay on the Immediate Data of Consciousness (George Allen \& Co, 1913), 101.

${ }^{20}$ Bergson, Essai sur les données immédiates de la conscience, 76; Henri Bergson, Durée et Simultanéité. À Propos de La Théorie d'Einstein (Presses Universitaires de France, 2009), 46.

${ }^{21}$ The charge of "spatialised time" refers to the application of spatial categories to consciousness: it is not equivalent to the frequent charge, directed at eternalists or B-theorists, that they "spatialise time." Bergson's charge of spatialising applies to A- and B-theorists equally, since it is not a claim about temporal ontology, but a claim about the temporal representation of consciousness. See especially Philippe Soulez and Frédéric Worms, Bergson. Biographie (Flammarion, 1997), 56; Worms, "Les trois dimensions de la question de l'espace dans l'œuvre de Bergson".

22 Bergson, Essai sur les données immédiates de la conscience, 72-73.

${ }^{23}$ See Bertrand Russell, "The Philosophy of Bergson", The Monist 22, no. 3 (1912); Karin Costelloe, "An Answer to Mr Bertrand Russell's Article on the Philosophy of Bergson", The Monist 24, no. 1 (1914); see also Frédéric Worms, “Bergson entre Russell et Husserl: Un troisième terme?”, Rue Descartes, no. 29 (2000).
} 
is not an obscure concept, and language can very successfully point us to what the term itself refers to.

In Creative Mind, Bergson provides the following account of la durée, as the gradual movement of mental states in our consciousness:

It is ... [an] indivisible and indestructible continuity of a melody where the past enters into the present and forms with it an undivided whole which remains undivided and even indivisible in spite of what is added at every instant ... [A]s soon as we seek an intellectual representation of it we line up, one after another, states which have become distinct like the beads of a necklace...$^{24}$

It is a succession of states each one of which announces what follows and contains what precedes. Strictly speaking they do not constitute multiple states until I have got beyond them and turned around to observe their trail. ${ }^{25}$

\section{In Time and Free Will Bergson describes la durée as a}

qualitative multiplicity, with no likeness to number; an organic evolution ... ; a pure heterogeneity within which there are no distinct qualities. In a word, the moments of inner duration are not external to one another. ${ }^{26}$

In la durée, the preceding states of consciousness have a qualitative influence on the ones that follow. For example, whenever we read a new book, our attitude and aesthetic feeling derived from the act of reading contain the series of mental states (emotions, memories) leading up to its reading. Similarly, whenever we read the same book again, the memories of past instances of its reading are "included" in the act of reading it at the present time; "included" not in the sense of containment, but "included" in that the present reading of the book would have been different without the past one. For this reason, la durée is unrepeatably different at every point of its development. Bergson also describes la durée with the seemingly contradictory phrase of "qualitative multiplicity," which is clarified by Pilkington as follows:

The notion of 'qualitative plurality' might seem a contradictory one, since to speak of a 'plurality' at all is to envisage the particulars which compose it as being in some sense juxtaposed, ... . Bergson however is compelled to use whatever resources language offers him, in order to describe duration; to grasp the notion of 'pure duration,' one must conceive of a succession, which is not separated into a series of discrete states; it is a series of qualitative transformations which flow into each other ... ${ }^{27}$

\footnotetext{
${ }^{24}$ Bergson, Creative Mind, 55.

${ }^{25}$ Bergson, Creative Mind, 137.

${ }^{26}$ Bergson, Time and Free Will. An Essay on the Immediate Data of Consciousness, 226.

${ }^{27}$ A. E. Pilkington, Bergson and His Influence. A Reassessment (Cambridge University Press, 1976), 3-4.
} 
Furthermore, Bergson instructs us to observe that this ever-changing development of our consciousness must be construed as indivisible. Take Bergson's example of falling in love with someone: when introspecting ourselves, we can never clearly pinpoint the moment at which our feeling of mild affection "turned" into love - the transition from one to the other is as gradual as the progression from one colour to another on the colour spectrum. Where does one colour and the other begin? The colour spectrum ${ }^{28}$ can also be used to illustrate the following seemingly incompatible claims: according to Bergson, la durée (i) can never be precisely divided into distinct segments, (ii) proceeds in "succession" and (iii) it is a multiplicity. (i) The colour spectrum consists of a gradual change from one colour to another - all divisions of the spectrum into distinct colours ("green," "light blue," "yellow"), will always be imprecise. They result from the casting of a "spatial" net over the heterogeneous continuity of the spectrum in order to extract distinct elements from it. Once we divide it into separate colours, we lose the distinct feature of gradual progression, almost an imperceptible shift from one to the other. This is what Deleuze has in mind when he says that la durée cannot be divided without changing in kind. ${ }^{29}$ (ii) Nevertheless, the fact that the elements composing the spectrum cannot be divided does not exclude their succession, the change that happens as we go from one side of the spectrum to another; thus there is, paradoxically, a succession (i.e., continuous change) with no distinct elements that succeed (since in our immediate phenomenological perception of change, as opposed to its retrospectively broken-up representation, there are no distinct elements). (iii) Despite the fact that the spectrum is indivisible (or rather, that any division we impose upon it will always be imprecise and incapable of capturing the immediate phenomenological impact the spectrum has on us as we gradually move our attention from one colour to the next), it is nevertheless a multiplicity (otherwise it would simply be one, consisting of a single colour).

The metaphor of the colour spectrum can further be used to illustrate another paramount concept of Bergson's philosophy, that of what Vladimir Jankélévitch refers to as "the illusion of retrospectivity." ${ }^{30}$ Consider the experience of looking at an LED lamp that changes so that it gradually goes through the entire colour spectrum. What is the most

\footnotetext{
${ }^{28}$ See Bergson, Essai sur les données immédiates de la conscience, 42.

${ }^{29}$ Gilles Deleuze, Bergsonism (Zone Books, 1991), 40.

${ }^{30}$ Vladimir Jankélévitch, Henri Bergson (Duke University Press, 2015), 11-17.
} 
accurate description of the way our consciousness perceives the LED lamp? At the moment of looking at it, its changing qualia form a continuous shift of one quality to another - we can only isolate distinct colours in it by "jumping back" in our mind by a few seconds and identifying that the colour, say, green has just turned into blue. Furthermore, we can lay out all of our memories of the colours in the past and turn them into the colour spectrum itself which becomes spread out in two-dimensional or three-dimensional space. It is only on this spectrum itself that we may impose imperfect divisions of colours and establish relations of before and after. This is what Bergson has in mind when he says that "Strictly speaking [states of consciousness] do not constitute multiple states until I have got beyond them and turned around to observe their trail." The present of la durée is indivisible: "when we think we are dividing it, we are dividing its spatial transcription ... ." ${ }^{\prime 31}$ Similarly, when looking at the lamp, we cannot differentiate the individual colours. The relation between the LED lamp and the spatially represented colour spectrum it goes through is analogous to that between la durée and the image it has left of itself in our memory.

The relation between la durée and the trace of its development in our memory also partially clarifies the claim about indivisibility of la durée from point (i) above; the prohibition on construing la durée as indivisible is not a contribution to the debate about whether time is discrete (i.e., that a moment of time cannot be further divided into smaller moments) or continuous (i.e., that for any two moments of time, there is another moment between them), it is rather an observation that the negotiation of these questions applies to spatialised time only (which constitutes the form through which we perceive our past), but cannot apply to the phenomenology of our immediate temporal experience. ${ }^{32}$ Regardless of whether objective time measured by clocks in the external world is divisible or indivisible, la durée, or the time of consciousness, is indivisible. Similarly, although it might be objected that the colour spectrum can always be divided, albeit imperfectly, Bergson's point is to stress that the division cannot be accomplished without changing the nature of the thing being divided. Before the division, we have a gradual qualitative progression from one

\footnotetext{
31 "Quand on croit la diviser, on divise [sa] transcription spatiale ...." Milet, Bergson et le calcul infinitésimal ou La raison et le temps, 55 my translation.

${ }^{32}$ As I have mentioned above, in Bergson's later works, la durée moves outwards and, as a category, is applied to the totality of physical reality. The limitations of this paper force me to put questions of temporal ontology on the side; here I am primarily limiting Bergson's contribution to questions of the phenomenology of temporal experience and thus focus mainly on his earlier works.
} 
colour to another (either as we move our eyes from one side of the spectrum to another or as we observe the LED lamp), after the division we move from one colour to another in sudden jumps. While the gap between the quality of the thing before division and after division may not seem so strange in the case of colours, in the case of the feeling of falling in love with someone that I have mentioned above, we can notice a much more radical difference between the presently lived experience of a continuous development of our mental states (e.g., emotions towards the person loved), the indivisible process of falling in love with someone, and the retrospective identification of various stages of this process ("vague interest" at $t_{1}$, strong affection" at $t_{2}$ and "love" at $t_{3}$ ).

Apart from stipulating the realm of la durée and that of spatial multiplicity, which intrudes into the pure heterogeneity of our mental states as a "ghost of space haunting the reflexive consciousness," ${ }^{33}$ Bergson also provides an analysis of how this intrusion takes place. He argues that the phenomenon of movement is one where space and la durée come dangerously close; dangerously so, because they become mixed. Frédéric Worms describes the process of our consciousness grasping movement in a twofold manner. On the one hand, there is what he calls "temporalisation of space" (temporalisation de l'espace ${ }^{34}$ ) - the moving body is grasped by our durée; it is only thanks to our memory as conscious beings that movement and change can be perceived in the external world in the first place. Imagine watching the movement of a clock pendulum from left to right:

Outside of me, in space, there is never more than a single position of the hand and the pendulum, ... It is because I endure ... that I picture to myself what I call the past oscillations of the pendulum at the same time as I perceive the present oscillation. Now, let us withdraw for a moment the ego which thinks these so-called successive oscillations: there will never be more than a single oscillation, and indeed only a single position, of the pendulum, and hence no duration. ${ }^{35}$

On the other hand, this process also causes the "spatialisation of la durée" (spatialisation de la durée $\left.{ }^{36}\right)$. Now, Bergson claims that movements of objects are given to consciousness as undivided singular qualities. ${ }^{37}$ By shifting our attention from the indivisible qualitative impression of movement of the moving object (best observed in the example of quickly

\footnotetext{
${ }^{33}$ Bergson, Time and Free Will. An Essay on the Immediate Data of Consciousness, 95.

${ }^{34}$ Worms, "Les trois dimensions de la question de l'espace dans l'œuvre de Bergson", 93.

${ }^{35}$ Bergson, Time and Free Will. An Essay on the Immediate Data of Consciousness, 108.

${ }^{36}$ Worms, "Les trois dimensions de la question de l'espace dans l'œuvre de Bergson", 93.

${ }^{37}$ Bergson, Matière et mémoire. Essai sur la relation du corps à l'esprit, 209-15.
} 
moving objects, e.g., of a falling star ${ }^{38}$ ) to the trajectory in space traversed by that movement, we inevitably come to identify it with the trajectory itself. Furthermore, since the moments of our durée are connectible with positions of space where the object was at different points of the trajectory and since this trajectory (qua a curve or a line in space) is geometrically divisible, we come to think that this divisibility applies to the durée which constituted the original experience of perceiving the movement as well. ${ }^{39}$ Thereby we make two mistakes: first, we fail to see that all movement is given to our consciousness as pure quality; second, we import all the categories pertaining to the completed trajectory of the moving object to durée.

On a side note, it is for all these reasons that Bergson argues that la durée is inaccessible to mathematics. For example, in measuring speed, we focus on simultaneities between the positions of moving objects in space to establish relations between them, but the durée which constituted our being able to perceive movement in the first place does not appear in the equations. ${ }^{40}$ Once the movement has taken place, we note the position of the body at point $A$ and then at point $B$ and compare these with the positions of, say, the hands of a clock; the movement itself which happens between the end and starting point disappears. "Velocity is therefore only a measurement of immobilities in comparison, it indicates the extremities of movement, not the interval." ${ }^{41}$ Furthermore, mechanics, Bergson argues, always operate with facts taken as accomplished, never with acts being accomplished $^{42}$ and since, as has been argued above, the fait accompli refers merely to the trace which la durée has left in its past and not to la durée, la durée itself does not and cannot appear in mechanical equations. It is here important to keep in mind that Bergson's accusation against the objective mathematical description of time is not that it is logically inconsistent, but rather that it fails to grasp the phenomenological aspect of change in our consciousness. The difference between the time of physics and the time of consciousness can be clarified by considering Le Poidevin's discussion of a psychological experiment with children conducted by Jean Piaget, which demonstrated that despite an objectively

\footnotetext{
${ }^{38}$ Bergson, Durée et Simultanéité. À Propos de La Théorie d'Einstein, 93.

${ }^{39}$ This is treated at length in Bergson, Durée et Simultanéité. À Propos de La Théorie d'Einstein, 41-67; see also Henri Bergson, La Pensée et le mouvant. Essais et conférences (Presses Universitaires de France, 2013), 157-62.

${ }^{40}$ Bergson, Durée et Simultanéité. À Propos de La Théorie d'Einstein, 67.

41 John Mullarkey, Bergson and Philosophy (Edinburgh University Press, 1999), 16.

${ }^{42}$ Bergson, Essai sur les données immédiates de la conscience, 89.
} 
homogeneous movement of water between two flasks of different shapes, the children report that the time it took for the water to move was different, depending on the shape of the flask, thus pointing to a gap between external objective temporality and time of consciousness. ${ }^{43}$ Le Poidevin says:

For these children, suggests Piaget, ..., time is plastic: it expands when the movement of water is slow, and contracts when the movement is fast. A greater displacement of water, or, more generally, a greater amount of activity, must, on this view of the world, take more time. ${ }^{44}$

Piaget interprets this rather bizarre phenomenon superficially appearing to involve "an incorrect understanding of the relationships between motion (or change in general), speed, and duration" 45 by the child's egocentric understanding of time, an understanding which has not yet reached the stage of grasping time as homogeneous and uniform. ${ }^{46}$ Bergson, on the other hand, would phrase the meaning of the above experiment differently. He would claim that although the position and physical "speed" of the water moving from the top vessel to the bottom one may have been equal, the internal experience that this has caused in the children's durée was different - nevertheless, the children's subjective perception of the water moving was required for them to talk about temporal experience in the first place.

\section{Atemporal Duration}

Putting Bergson aside for the time being, I will now provide a brief outline of Stump and Kretzmann's concept of "atemporal duration" and the most significant objections against it following the publication of "Eternity" in $1981 .{ }^{47}$

Stump and Kretzmann's discussion of eternity begins by identifying four aspects of Boethius' famous definition of eternity as "simultaneous and perfect possession of boundless life" (interminabilis vitae tota simul et perfecta possessio). ${ }^{48}$ (i) God has a life.

\footnotetext{
${ }^{43}$ Robin Le Poidevin, The Images of Time. An Essay on Temporal Representation (Oxford University Press, 2007), 34-35.

${ }^{44}$ Le Poidevin, The Images of Time. An Essay on Temporal Representation, 35.

${ }^{45}$ Le Poidevin, The Images of Time. An Essay on Temporal Representation, 35.

${ }^{46} \mathrm{~J}$. Piaget, The Child's Conception of Time (Routledge \& Kegan Paul, 1969), 48.

${ }^{47}$ As I mentioned in my introduction, this section is concerned only with atemporal duration and not with ET-simultaneity, which I take to be separable from it.

${ }^{48}$ Boethius, The Consolation of Philosophy, 422-25.
} 
Eternity is not comparable to the mode of existence of, for example, universals, numbers or truths. ${ }^{49}$ (ii) God's life is illimitable: it has neither a beginning nor an ending in time. While Stump and Kretzmann briefly consider the possibility of this "illimitability" referring to the lack of limits of a single instant of time ("what cannot be extended, cannot be limited in its extent" ${ }^{\prime 50}$ ), in the end, they read Boethius' understanding of eternity as "beginningless, endless, infinite duration." ${ }^{51}$ (iii) God's life is a duration. While they do acknowledge that it is a duration of "a special sort," 52 this follows directly from their understanding of "illimitability" from the preceding point. (iv) God possesses his entire life at once (tota simul). According to them, all the "events" of God's life are mutually simultaneous. These four points, in turn, lead them to conclude that eternity is an "atemporal duration," which is characterised by the following four features:

First, there is no earlier or later in God's life: its events are mutually simultaneous and present, but cannot be sequentially ordered. ${ }^{53}$ They also argue that there cannot be subphases of this duration. ${ }^{54}$ Second, while eternity is a duration, it is a duration that does not consist of a succession of events: "no eternal entity has existed or will exist, it only exists." ${ }^{55}$ Third, the sense of "duration" in "atemporal duration" cannot be taken to mean "persistence through time," as it is used in common parlance. Stump and Kretzmann acknowledge that such a sense of "duration" "violates established usage: but [that] an attempt to convey a new philosophical or scientific concept by adapting familiar expressions is not to be rejected on the basis of its violation of ordinary usage." ${ }^{56}$ Moreover, they believe that atemporal duration grounds all other forms of duration. Replying to Nelson who criticises them for being caught in either an equivocal or a univocal use of "duration" in relation to God and temporal phenomena, ${ }^{57}$ Stump and Kretzmann argue for an analogical use of "duration" and conclude that

\footnotetext{
${ }^{49}$ Stump and Kretzmann, "Eternity", 431.

50 Stump and Kretzmann, "Eternity", 432.

${ }^{51}$ Stump and Kretzmann, "Eternity", 433.

52 Stump and Kretzmann, "Eternity", 433.

${ }^{53}$ Stump and Kretzmann, "Eternity", 434.

54 Eleonore Stump and Norman Kretzmann, "Atemporal Duration. A Reply to Fitzgerald", The Journal of Philosophy 84, no. 4 (1987), 219.

55 Stump and Kretzmann, "Eternity", 434.

${ }^{56}$ Stump and Kretzmann, "Eternity", 446.

57 Herbert J. Nelson, “Time(s), Eternity, and Duration”, International Journal for Philosophy of Religion 22, no. 1/2 (1987), 12.
} 
[a]temporal duration is the genuine, paradigmatic duration, of which temporal duration is only the moving image. ... [I]t is the basis of all temporal duration, any instance of which is correctly called duration only analogically since it is only a partial manifestation of the paradigmatic, genuine duration ... ."158

Fourth, despite atemporal duration's indivisibility, successionlessness and complete simultaneity, Stump and Kretzmann believe that Boethius' duration is an extended duration, an "infinitely enduring" present. ${ }^{59}$

Soon after the publication of "Eternity," objections against "atemporal duration" began to appear. While it is impossible to capture the entirety of the debate, the three strongest objections against Stump and Kretzmann's position can be classified under three headings:

The first objection states that "atemporal duration" cannot be a "duration" at all, since a "duration" is an extension and "atemporal duration" does not satisfy conditions for extensionality. For example, Fitzgerald observes that for any duration, it must be possible that "two particulars may both have the same or a different amount of the mode of extension in question." 60 This means that even if atemporal duration is infinitely extended, there must, at least in theory, be distinct subphases of duration, otherwise to apply the term extension to atemporal duration does not make sense. However, as has been mentioned above, Stump and Kretzmann reject the possibility of "atemporal duration" having distinct subphases. Fitzgerald concludes that for this reason in atemporal duration "we do not really have an extensive mode in eternality at all, given not only that past and future and earlier and later are inapplicable, but that there is no analogue of them.." ${ }^{\prime 1}$

The second objection concerns the problem of "atemporal duration" being a timelike extension. In 1990, Leftow observed that "duration" in the Stump-Kretzmannian reading is supposed to be a timelike extension, although the use of "timelike" in this sense is of course highly analogical, as Stump and Kretzmann themselves concede. ${ }^{62}$ However, one cannot coherently speak of atemporal duration as a timelike extension in the way that they imagine because it leads to the following problem: "Arguably, what contains no distinct

\footnotetext{
58 Stump and Kretzmann, "Atemporal Duration. A Reply to Fitzgerald", 219.

59 Stump and Kretzmann, "Atemporal Duration. A Reply to Fitzgerald", 219.

60 Paul Fitzgerald, "Stump and Kretzmann on Time and Eternity", The Journal of Philosophy 84, no. 5 (1985), 262.

${ }^{61}$ Paul Fitzgerald, "Stump and Kretzmann on Time and Eternity," The Journal of Philosophy 84, no. 5 (1985): 262.

62 See Stump and Kretzmann, "Atemporal Duration. A Reply to Fitzgerald”.
} 
points is not an extension at all [see Fitzgerald], and what contains distinct points, but not points ordered as earlier and later, may be an extension, but lacks the traits distinctive of temporal extension." ${ }^{\prime 63}$

The third objection attacks the possibility of "duration" in "atemporal duration" being used in a sense analogical to "duration" in the temporal realm. This option was proposed by Stump and Kretzmann in their response to Fitzgerald to avoid the charge that "duration" in "atemporal duration" is used in an extremely deviant sense that has nothing in common with ordinary usage. ${ }^{64}$ Unfortunately, as Rogers observes, ${ }^{65}$ the appeal to analogy does not help. It does not seem like our experience, where we first encounter perfections predicable of God, presents us with anything at all that we could use to get a hold of atemporal duration or to use as a basis for analogising up to "atemporal duration:" "If we cannot, in however limited a way, show where the similarity lies between Creator and creature, we may use the same word of both, but we are using it equivocally." ${ }^{66}$

\section{Atemporal Durée}

The temporal development of our consciousness is roughly divided into two segments, with imprecise boundaries between them. On the one hand, there is that part of our consciousness consisting of the present moment. This roughly corresponds to what is sometimes referred to as the "specious present." 67 On the other hand, there is the past of our consciousness, accessible by memory. Now, the proportion of these two parts of our conscious history is different from person to person - some people can focus their attention for two or three seconds, some for more. Nevertheless, for all creatures whose consciousness develops in time, there is a qualitative difference between perception and memory. Now, Bergson states that this distinction must be held in conjunction with the conceptual difference between la durée and its trace in the past. It is only when we

\footnotetext{
${ }^{63}$ Leftow, "Boethius on Eternity", 128.

${ }^{64}$ Stump and Kretzmann, "Atemporal Duration. A Reply to Fitzgerald"; see also Eleonore Stump and Norman Kretzmann, "Eternity, Awareness, and Action", Faith and Philosophy 9, no. 4 (1992).

${ }^{65}$ Katherin A. Rogers, “Eternity Has No Duration”, Religious Studies 30, no. 1 (1994).

${ }^{66}$ Rogers, "Eternity Has No Duration", 14.

${ }^{67}$ For a discussion of this notion endorsed by Bergson, see William James, The Principles of Psychology (Cambridge, Massachusetts: Harvard University Press, 1983); see also Le Poidevin, The Images of Time. An Essay on Temporal Representation, 80; Sean Enda Power, "The Metaphysics of the 'Specious' Present," Erkenntnis 77, no. 1 (2012): 121-32.
} 
remember the past development of la durée that we may attempt to identify distinct moments in is trace, stipulate relations of "before" and "after," similarly to the way that we may split the memory of the immediate phenomenological perception of the LED lamp into distinct colours. In la durée, as it is developing, no such divisions can be made.

Now, imagine gradually extending the present attention of our consciousness into the past. For example, most people are able to focus their attention on one or two sentences at a time - imagine someone who could hold in one act of consciousness the entire act of reading a book, then a library etc. As we keep extending this present attention of la durée, the proportion between memory and present perception decreases. Finally, let us imagine a consciousness with such perfect attention that its durée would perfectly coincide with its memory. The entirety of its conscious life (which is for human beings separated into the past and the present) would always be present, still developing (as the phenomenological qualia-like impression of the LED lamp) as a constant movement of consciousness. Bergson himself hypothesises such a durée as follows:

An attention ... sufficiently powerful ... would thus include in an undivided present the entire past history of the conscious person, - not as instantaneity, not like a cluster of simultaneous parts, but as something continually present, which would also be something continually moving: such, I repeat, is the melody which one perceives as indivisible, and which constitutes, from one end to the other ... a perpetual present, although this perpetuity has nothing in common with immutability, or this indivisibility with instantaneity. What we have is a present which endures. ${ }^{68}$

My claim is that "atemporal duration" should be understood as such a "perpetual present," i.e., la durée. This special instance of la durée can be characterised as follows:

First, the "time" of divine life as understood along Bergsonian lines is radically opposed to the temporal categories of mathematical or physical time. It is the time of consciousness, not a potentially infinitely divisible continuum with clear outlines, subphases, instants and points since divisions can only be effected imperfectly on the trace in the past of our durée. In this respect, God is temporal if "time" is taken as the time of consciousness, that is, durée, but God is timeless if "time" is taken as the objective time applicable to the external world. God's life is an indivisible partless change.

Second, whenever we find ourselves speaking of distinct separable events in God's life (e.g., of His "speaking to Moses" before "sending His Son"), we are only looking back at

\footnotetext{
${ }^{68}$ Bergson, Creative Mind, 127.
} 
the time passed in our durée, directly accessible by memory, and not time passing. We cannot separate such events in God's durée in se, only in the trace it has left in our durée, quoad nos. That is because when we consider that God's time is a "perpetual" continuously developing indivisible present, we realise that to speak of distinct events in God's durée is as contradictory as identifying distinct subphases in the development of our present attention.

We cannot individuate mental states in our durée, but only once they have taken place and have become memory. This awareness of the difference between growing memory and perception is precisely what constitutes our awareness of the passage of time. Similarly, the development of God's durée is indivisible as it is happening (which is always, i.e., the entirety of his durée is "ET-simultaneous" with every point of our durée), but we can conceive of its traces in our past being divided once certain events have happened from our temporal perspective and have become part of the memory of our durée. We see them in our past because our "specious present" is complemented by our memory. In the case of God, on the other hand, there is no separation between present and past. ${ }^{69}$ The reason why we cannot ask about the trace of past moments in God's life in se is that, in se, there is no such trace - God's memory perfectly overlaps with his present phenomenological attention. However, we may do so quoad nos, since those moments that have manifested themselves in our past are now retained by our memory and are thus subject to the topology of spatialised time. In this sense, there is "order" of events in divine life, but we must constantly be aware that when speaking of such an order, we are moving at the level of events that have been retained in our own memory. Now, the claim that God's time is a perpetual, continuously developing, indivisible present seems to involve blatant contradictions. How can something change without going through stages of change? Responding to the charge of contradictions in Bergson's definition of la durée would involve going into Bergson's theory of language, and the way it relates to la durée, which is beyond the scope of this paper. However, in passing, it should be stressed that the objective of Bergson's method is not to provide a precise definition of la durée, but rather to use

\footnotetext{
${ }^{69}$ For a brief discussion of the possibility of conceiving God's knowledge of the world as specious present, see William P. Alston, "Hartshorne and Aquinas: A Via Media", in Divine Nature and Human Language. Essays in Philosophical Theology (Cornell University Press, 1989), 136; Stump and Kretzmann, "Eternity, Awareness, and Action", 468. Cf. Alston: "Even though I perceive one-twentieth of a second all at once, l, and my awareness, are still in time, ... But a being with an infinite specious present would not, so far as his awareness is concerned, be subjected to temporal succession at all. ... Everything would be grasped in one temporally unextended awareness." (Alston, 136)
} 
language to point us to the fundamental experience of temporality immediately furnished by our consciousness, which has been covered up by inappropriate forms of thought borrowed from a realm inapplicable to it. When we are in the act of perceiving change, we are perceiving it as indivisible - in this respect, the change in our durée is indivisible and yet changing. The prima facie self-contradictory move of holding together both the notion of an "infinite specious present" and "temporally unextended awareness" suggested by Alston (see footnote 69) is further commented on by him as follows:

The psychological concept of the specious present is intended to embody the possibility that one might be aware of a process without successively being aware of its temporal parts. But this does not imply that the awareness itself is a process without succession. ... [T] stages of [God's] life will not occur successively in time but will occur or 'be given' in one unity of felt immediacy. ${ }^{70}$

Third, the experience of such a durée is phenomenologically inaccessible to us. Some durées are completely unimaginable to ours because their rhythm is faster, more intense than that of our own, for example, the consciousness of a hypothetical human being able to perceive the spinning of electrons. Others are inaccessible because they are far slower, e.g., that of a hypothetical human able to perceive the movement of continents. ${ }^{71}$ Moore provides a fascinating illustration of this point:

The story is told how Wittgenstein was walking with friends, and suggested that they should act out the solar system. ... The real difficulties [of this game] are temporal. For to keep an apparent circular motion round my sun, I shall have to change my speed at each moment, going faster when I am going in the direction of the sun, and slowing down when I am going in the other direction. ... If moon-Wittgenstein is to go at a feasible speed, the earthhusband will have to be going very slowly, and the motion of the sun-wife will need to be imperceptible. ... In short, the experience of temporal process required by the game is inaccessible to us. $^{72}$

Fourth, God has a life. But His life must be construed as an indivisible progress. The seemingly contradictory description of la durée as "indivisible change" has been clarified in section 2 with regards to the LED lamp and colour-spectrum examples; the paradoxical

\footnotetext{
${ }^{70}$ Alston, "Hartshorne and Aquinas: A Via Media", 138-39.

${ }^{71}$ Here the term "faster" is used merely metaphorically to capture the difference between the "intensity" of different durées, i.e., the dimensions of their "specious present" in proportion to its memory and the number of impressions or perceptual inputs that the specious present is capable of capturing. A good illustration can be supplied by Le Poidevin's discussion of a patient with a brain injury for whom ordinary movements of objects would be happening to past to perceive. See Le Poidevin, The Images of Time. An Essay on Temporal Representation, 107-8.

72 Francis Charles Timothy Moore, Bergson: Thinking Backwards (Cambridge University Press, 1996), 60 my italics.
} 
notion of "indivisible progress" refers to the phenomenological awareness of change in our present attention which is indivisible. Our "specious present" is given to us as an indivisible unit of qualitative change, which is only divisible retrospectively, once the specious present has become part of our memory. By looking back at God's past dealings with the world, in which we can isolate events and speak of “God's knowing something at 15:00" and "God's knowing something at 15:01," we are not operating at the level of God's durée. An understanding of divine "time" as la durée means that there is "change" and development in God, but not a separation into temporal parts. He is "timeless" insofar as He is not divisible into temporal parts pertaining to physical time (since dividing His life in such a way implies operating on the mere shadow of the durée), but not "timeless" in the sense of there not being change in Him, although "change" here is used in the Bergsonian sense applicable to the phenomenology of temporal experience in consciousness.

How does identifying "atemporal duration" with la durée respond to the objections against Stump and Kretzmann raised at the end of section 3? First, from a Bergsonian perspective, Fitzgerald's requirement for atemporal duration to consist of different "amounts" of duration does not make sense - we can speak of "amounts" of space (centimetres, metres), or amounts of physical time (hours, minutes), but not of durée, which is pure heterogeneous quality and therefore unquantifiable. By the same token, since God's atemporal duration is durée which is happening, it does not make sense to speak of "positions" or "points" in it - when we are conceptualising divine eternity in such a way, we are merely looking back at God's actions in our time as they happened in our own temporal perspective and as they are retained by our memory. In this respect the separation between our durée (separated into present attention and memory) and divine durée (the attention of the perpetual present) maps onto the following distinction posited by Stump and Kretzmann:

[atemporal duration] is not made up of components at all, actual or potential; instead, it is potentially divisible conceptually.... [I]n his own nature God is pure actuality, but nothing in that claim prohibits our conceiving of God as successively actualizing various potentialities, when we conceive of him from our temporal point of view. ${ }^{73}$

\footnotetext{
${ }^{73}$ Stump and Kretzmann, "Atemporal Duration. A Reply to Fitzgerald," 216, first italics original, second mine.
} 
Furthermore, this divisibility quoad nos only refers to the traces that God's being has left in our memory. Whilst Stump and Kretzmann in the quote above speak of conceiving, in the present, of God as actualising possibles, on the Bergsonian reading this should only be limited to referring to the past as it is remembered by humans, to actions that God has performed before the present we are currently perceiving.

Second, similar considerations apply to Leftow's objection - the atemporal durée does not contain points, either in succession (as he accuses Stump and Kretzmann of claiming) or points ordered by earlier/later relations. These can only be specified in retrospect. Nevertheless, its time-likeness is constituted by the analogical process of gradually overlapping our present attention and memory (which are clearly in a time-like relation). On the other hand, its "atemporality" is constituted by the impossibility of separating it into subphases in itself, but merely in its manifestation to our durée in the created realm.

Third, this way of conceiving God's durée provides sufficient grounds for describing it as analogical. God's durée is analogical to ours since our durée shares with His complete indivisibility. The indivisibility of the present attention constitutes the overlap, the similarity, with divine durée, the separation of our durée into present attention and memory constitutes the difference. We could imagine a hierarchy of durées (from Le Poidevin's patients with brain injuries, through hypothetical people observing the movement of continents) going all the way up to God. In this way, God's durée is at least conceptually related to ours. Nevertheless, it is also qualitatively different from ours, since it is always attentive to itself, with no separation between present perception and past memory in its perpetual present. By positing hypothetical entities whose attention spans longer and longer portions of human time, we can imagine ascending up to it, though never fully grasping it, since our own thought, even when perceiving our own selves, let alone conceiving of God, will always be subject to the separation of (i) the retrospectively divisible, line-like memory of our consciousness isolatable into distinct mental states and (ii) our present attention. 


\section{Objections}

It may be argued that although the identification of la durée with atemporal duration solves the three objections from above, it generates problems of its own.

The first problem concerns the ontological relationship between divine durée and our durée, which poses the following dilemma. On the one hand, Bergson argues that our consciousness clearly presents us with a "now" constituted by the conscious present and that for our durée the future does not exist in any sense. This seems to commit Bergson to presentism or the growing-block theory of time. On the other hand, I have argued that God's durée merges memory and perception into a single indivisible perpetual present. Since God's knowledge of Himself is identical with His knowledge of the world, it seems that (our) future must in a way exist in order for Him to know it. ${ }^{74}$ This seems to commit the model outlined above to eternalism. Which one do we accept? As I have mentioned above, this is not a problem unique to the Bergsonian take on "atemporal duration" presented in this paper, but a problem for any conception of divine eternity which insists both on omniscience and free will. However, Bergson aside, I agree with Shanley who claims that the focus on the debate about temporal ontology and God should be shifted to the utter dependency of creation on its Creator. ${ }^{75}$ For example, the question of whether God knows the future depending on whether it is already "there," as eternalism seems to imply ${ }^{76}$ or whether he does not because it does not yet exist, as presentism or growing-block seem to suggest, is simply the wrong type of question to ask. God knows the future because he creates it, not because it is there or will be there for his "perceptual knowledge" to access. Theologians should move away from the tendency to first picture independently existing temporal reality (Bergsonian or not), then an independently existing God and trying to establish epistemic relations between them, especially considering the fact that this project usually tends to fail. Once we shift our focus from independent temporal ontology to God's

\footnotetext{
${ }^{74}$ See for example D. H. Mellor, "History Without the Flow of Time", Neue Zeitschrift Für Systematische Theologie Und Religionsphilosophie 28 (1986); William Lane Craig, "Was Thomas Aquinas a B-Theorist of Time?", New Scholasticism 59, no. 4 (1985).

75 See Brian J. Shanley, "Eternal Knowledge of the Temporal in Aquinas", American Catholic Philosophical Quarterly 71, no. 2 (1997); see also Brian J. Shanley, “Aquinas on God's Causal Knowledge: A Reply to Stump and Kretzmann", American Catholic Philosophical Quarterly 72, no. 3 (1998); Brian J. Shanley, "Divine Causation and Human Freedom in Aquinas", American Catholic Philosophical Quarterly 72, no. 1 (1998); Eleonore Stump and Norman Kretzmann, "Eternity and God's Knowledge: A Reply to Shanley", American Catholic Philosophical Quarterly 72, no. 3 (1998).

${ }^{76}$ See for example Mellor, "History Without the Flow of Time".
} 
creative action, it is not so surprising that, as Mullins points out, most of the medieval theologians insisting on eternity, omniscience and free will, were, rather counterintuitively, presentists. ${ }^{77}$

The second objection concerns the difference between divine atemporal duration (or atemporal "durée") and human duration. I have shown that there is sufficient overlap between our durée and divine durée. But has the distinction between them not collapsed? If our durée is indivisible and God's durée is too, also characterised by a perpetual change, does anything prevent us from saying that our own consciousness is also an example of atemporal duration? Here the response is rather simple; there is an analogy between our durée in the present moment and the divine atemporal duration, but ours is different since we are subject to progression in time and the separation of present perception and memory. Nothing of this sort applies to the divine durée.

Third, it may be objected that we cannot identify time with consciousness. Some philosophers indeed draw a tight connection between consciousness and time (thus qualitatively differentiating time from space which, arguably, can be conceived without appeal to the presence of a human mind). ${ }^{78}$ I have not shown that time is dependent for its existence on the human mind. To respond to the first objection, I must reiterate the claim from my Introduction where I have intentionally limited Bergson's durée to consciousness. As has been demonstrated above, to move away from physical time as a means of fleshing out the content of "atemporal duration" and instead model its properties on la durée as a more accurate way of capturing the phenomenological qualia of consciousness provides a more coherent way of conceiving atemporal duration. This move away from physical time to la durée, with its concomitant distinction between perception and memory (i.e., the present and past of consciousness) also explains why certain topological features of physical time (e.g., its divisibility into distinct segments, points etc.) are inapplicable to la durée and, by extension, to Stump and Kretzmann's "atemporal duration."

\footnotetext{
77 See Mullins, The End of the Timeless God, 74-86.

${ }^{78}$ See for example J. R. Lucas, A Treatise on Time and Space (Methuen \& Co, 1973), 7-16.
} 


\section{Conclusion}

By way of conclusion, it might be objected that I have merely blurred the distinctions between divine timelessness and divine temporality. In what respect is the "perpetual present" a version of divine timelessness? Was not Stump' and Kretzmann's intention from the beginning to preserve the idea of a timeless duration? But here, it must be repeated that we are forced to make a distinction between timelessness and duration only if we accept physical, objective time as somehow providing the means for capturing the divine mode of being: it is time modelled on objects existing in the physical universe that forces us to decide between (i) God existing outside of physical time, thus having none (or not all) of the properties applicable to physical time or (ii) a God existing somehow in this physical time but not subject to some of its limitations. ${ }^{79}$ Neither of these has so far provided a satisfactory way of understanding what "atemporal duration" is. On the contrary, by moving to the phenomenology of time of consciousness, captured by Bergson's concept of la durée, we can not only remove some of the contradictions caused by importing the topology of physical time into "atemporal duration," but also use our own immediately accessible consciousness as a tangible bedrock on which to establish relations of analogy between human durée and divine durée. The Bergsonian "perpetual present" is atemporal in that it is not subject to change in physical time, but it is a "duration" in that it has a durée. ${ }^{80}$

\section{References}

Alston, William P. 1989. "Hartshorne and Aquinas: A Via Media". In Divine Nature and Human Language. Essays in Philosophical Theology, 121-43. Ithaca and London: Cornell University Press.

Bergson, Henri. 1913. Time and Free Will. An Essay on the Immediate Data of Consciousness. Translated by F. L. Pogson. London: George Allen \& Co.

- - . 2007. Creative Mind. Translated by Mabelle L. Andison. New York: Dover Publications.

- - - 2007. L'Évolution créatrice. Édition critique dirigée par Fréderic Worms. Volume edité par Arnaud François. Paris: Presses Universitaires de France.

\footnotetext{
${ }^{79}$ See e.g., Robert Pasnau, “On Existing All at Once," in God, Time and Eternity, ed. Christian Tapp and Edmund Runggaldier (New York: Routledge, 2016), 11-28.

${ }^{80} \mathrm{I}$ am greatly indebted to Sarah Coakley, Ryan Mullins, Jacob Sherman, anonymous reviewers of the EJPR and participants of the Summer School on The Nature of God: Personal and A-Personal Concepts of the Divine (Innsbruck, Austria, $25^{\text {th }}$ July $-9^{\text {th }}$ August 2018) for comments on earlier versions of this paper. This paper was supported by funding from a studentship hosted by the Cambridge Arts and Humanities Research Council Doctoral Training Partnership and Pembroke College, Cambridge.
} 
- - . 2009. Durée et Simultanéité. À Propos de La Théorie d'Einstein. Édition critique dirigée par Frédéric Worms. Volume edité par Elie During. Paris: Presses Universitaires de France.

- - . 2012. Matière et mémoire. Essai sur la relation du corps à l'esprit. Édition critique dirigée par Frédéric Worms. Volume edité par Camille Riquier. Paris: Presses Universitaires de France.

- - - 2013. Essai sur les données immédiates de la conscience. Édition critique dirigée par Frédéric Worms. Volume edité par Arnaud Bouaniche. Paris: Presses Universitaires de France.

- - . 2013. La Pensée et le mouvant. Essais et conférences. Édition critique dirigée par Frédéric Worms. Volume édité par Arnaud Bouaniche, Arnaud François, Frédéric Fruteau de Laclos, Stéphane Madelrieux, Claire Marin, Ghislain Waterlot. Paris: Presses Universitaires de France.

- - - 2016. Histoire de l'idée de temps. Cours au Collège de France 1902-1903. Paris: Presses Universitaires de France.

Boethius. 1973. The Consolation of Philosophy. Translated by S. J. Tester. Cambridge: Harvard University Press.

Coburn, Robert C. 1963. "Professor Malcolm on God". Australasian Journal of Philosophy 41, no. 2: 143-162.

Costelloe, Karin. 1914. "An Answer to Mr Bertrand Russell's Article on the Philosophy of Bergson". The Monist 24, no. 1: 145-155.

Craig, William Lane. 1985. "Was Thomas Aquinas a B-Theorist of Time?" New Scholasticism 59, no. 4: 475-83.

De Florio, C., and A. Frigerio. 2015. "In Defense of the Timeless Solution to the Problem of Human Free Will and Divine Foreknowledge". International Journal for Philosophy of Religion 78, no. 1: 5-28.

Deleuze, Gilles. 1991. Bergsonism. Translated by Hugh Tomlison and Barbara Habberjam. New York: Zone Books.

Deppe, Sonja. 2016. "The Mind-Dependence of the Relational Structure of Time (or: What Henri Bergson Would Say to B-Theorists)". Kriterion - Journal of Philosophy 30, no. 2: 107-24.

Diekemper, J. 2013. "Eternity, Knowledge and Freedom". Religious Studies 49, no. 1: 45-64.

Fitzgerald, Paul. 1985. "Stump and Kretzmann on Time and Eternity". The Journal of Philosophy 84, no. 5: 260-269.

Hankey, W. J. 2006. One Hundred Years of Neoplatonism in France: A Brief Philosophical History. Leuven, Paris and Dudley: Peters.

Hasker, William. 1989. God, Time and Knowledge. London and Ithaca: Cornell University Press.

Helm, Paul. 2009. "Eternity and Vision in Boethius". European Journal for Philosophy of Religion 1, no. 1: 77-97.

- - - 2010. Eternal God. A Study of God without Time. Second edition. Oxford: Oxford University Press.

Jäger, Christoph. 2013. "Molinism and Theological Compatibilism". European Journal for Philosophy of Religion 5, no. 1: 71-92.

James, William. 1983. The Principles of Psychology. Cambridge, Massachusetts: Harvard University Press. 
Jankélévitch, Vladimir. 2015. Henri Bergson. Translated by Nils F. Schott. London and Durham: Duke University Press.

Kant, Immanuel. 1998. Critique of Pure Reason. Translated by Allen W. Wood and J. Paul Guyer. Cambridge: Cambridge University Press.

Kneale, William. 1985. "Time and Eternity in Theology". Proceedings of The Aristotelian Society 61: 87-108.

Le Poidevin, Robin. 2007. The Images of Time. An Essay on Temporal Representation. New York: Oxford University Press.

Leftow, Brian. 1990. "Boethius on Eternity". History of Philosophy Quarterly 7, no. 2: 123-42.

Lewis, Delmas. 1984. "Eternity Again: A Reply to Stump and Kretzmann". International Journal for Philosophy of Religion 15, no. 1/2: 73-79.

Lucas, J. R. 1973. A Treatise on Time and Space. London: Methuen \& Co.

Mellor, D. H. 1986. "History Without the Flow of Time". Neue Zeitschrift Für Systematische Theologie Und Religionsphilosophie 28: 68-76.

Milet, Jean. 1974. Bergson et le calcul infinitésimal ou La raison et le temps. Paris: Presses Universitaires de France.

Moore, Francis Charles Timothy. 1996. Bergson: Thinking Backwards. Cambridge: Cambridge University Press.

Mossé-Bastide, Rose-Marie. 1959. Bergson et Plotin. Paris: Presses Universitaires de France. Mullarkey, John. 1999. Bergson and Philosophy. Edinburgh: Edinburgh University Press.

Mullins, Ryan T. 2013. "Simply Impossible: A Case Against Divine Simplicity". Journal of Reformed Theology 7, no. 2: 181-203.

- - . 2016. The End of the Timeless God. Oxford: Oxford University Press.

Mutch, A. 2016. "The Limits of Process: On (Re)Reading Henri Bergson". Organization 23, no. 6: 825-40.

Nelson, Herbert J. 1987. "Time(s), Eternity, and Duration". International Journal for Philosophy of Religion 22, no. 1/2: 3-19.

Olma, Sebastian. 2007. "Physical Bergsonism and the Worldliness of Time". Theory, Culture \& Society 24, no. 6: 123-137.

Pasnau, Robert. 2016. "On Existing All at Once". In God, Time and Eternity, edited by Christian Tapp and Edmund Runggaldier, 11-28. New York: Routledge.

Piaget, J. 1969. The Child's Conception of Time. Translated by J. A. Pomerans. London: Routledge \& Kegan Paul.

Pilkington, A. E. 1976. Bergson and His Influence. A Reassessment. London, New York and Melbourne: Cambridge University Press.

Power, Sean Enda. 2012. "The Metaphysics of the 'Specious' Present". Erkenntnis 77, no. 1: 121-32.

Riggio, Adam. 2016. "Lessons for the Relationship of Philosophy and Science From the Legacy of Henri Bergson". Social Epistemology 30, no. 2: 213-26.

Robbins, Stephen E. 2004. "On Time, Memory and Dynamic Form". Consciousness and Cognition 13: 762-788.

Rogers, Katherin A. 1994. "Eternity Has No Duration". Religious Studies 30, no. 1: 1-16.

Rota, Michael. 2010. "The Eternity Solution to the Problem of Human Freedom and Divine Foreknowledge". European Journal for Philosophy of Religion 2, no. 1: 165-86.

Russell, Bertrand. 1912. "The Philosophy of Bergson". The Monist 22, no. 3: 321-47.

Shanley, Brian J. 1997. "Eternal Knowledge of the Temporal in Aquinas". American Catholic Philosophical Quarterly 71, no. 2: 197-224. 
- - . 1998. "Aquinas on God's Causal Knowledge: A Reply to Stump and Kretzmann". American Catholic Philosophical Quarterly 72, no. 3: 447-57.

- - . 1998. "Divine Causation and Human Freedom in Aquinas". American Catholic Philosophical Quarterly 72, no. 1: 99-122.

Soulez, Philippe, and Frédéric Worms. 1997. Bergson. Biographie. Paris: Flammarion.

Stump, Eleonore, and Norman Kretzmann. 1981. "Eternity". The Journal of Philosophy 78, no. 8: 429-57.

- - . 1987. "Atemporal Duration. A Reply to Fitzgerald". The Journal of Philosophy 84, no. 4: 214-19.

- - . 1992. "Eternity, Awareness, and Action". Faith and Philosophy 9, no. 4: 463-82.

- - . 1998. "Eternity and God's Knowledge: A Reply to Shanley". American Catholic Philosophical Quarterly 72, no. 3: 439-45.

Swinburne, Richard. 1993. "God and Time". In Reasoned Faith: Essays in Honor of Norman Kretzmann, edited by Eleonore Stump, 204-22. Ithaca and London: Cornell University Press.

- - - 2016. The Coherence of Theism. Second edition. Oxford: Oxford University Press.

Williams, Clifford. 1996. "The Metaphysics of A- and B-Time". The Philosophical Quarterly 46, no. 194: 371-81.

- - . 1998. "A Bergsonian Approach to A- and B-Time". Philosophy 73, no. 285: 379-93.

Worms, Frédéric. 1994. "Les trois dimensions de la question de l'espace dans l'œuvre de Bergson". Épokhè 94, no. 4: 89-116.

- - - 2000. "Bergson entre Russell et Husserl: Un troisième terme?" Rue Descartes, no. 29: 79-96. 